\title{
HORNER'S SYNDROME AND BRACHIAL PARESIS AS A COMPLICATION OF LUMBAR SYMPATHETIC BLOCK
}

\author{
A CASE REPORT
}

\author{
P.A. MARANHĀO-FILHO*, M.A.O. MARTINS* ${ }^{\star}$, H.F. LOPES ${ }^{\star *}$
}

SUMMARY - An unusual case of Homer's syndrome secondary to a sympathetic block in a patient with chronic adhesive arachnoiditis (CAA) is described. The patient, a 40-year-old white woman, presented with spastic paraplegia, hyperreflexia, bilateral Babinski sign, superficial and deep sensitive hypoaesthesia at the T4 level, in addition to bladder and rectal dysfunction since she was 32. At age of 38 she complained of excessive daily sweating below the T4 level, mostly at night. A $4 \mathrm{~mL} 0.5 \%$ bupivacaine lumbar sympathetic block was performed. Within $15 \mathrm{~min}$ a right brachial paresis and an ipsilateral Horner's syndrome were noted. Speculatively, an abnormal cephalic spread of the anaesthesic due to a putative erratic space secondary to the CAA may justify the clinical picture even using a relatively small amount of anaesthesic $(4 \mathrm{~mL})$.

KEY WORDS: lumbar sympathetic block, chronic adhesive arachnoiditis, Horner's syndrome.

Síndrome de Horner e paresia braquial como complicação de bloqueio simpático lombar: relato de caso

RESUMO - Os autores descrevem o caso de uma mulher branca de 40 anos de idade, com paraplegia espástica, hiperreflexia, sinal de Babinski bilateral, hipoestesia superficial e profunda em T4, além de incontinência fecal e urinária, desde os 32 anos decorrente de aracnoidite crônica adesiva (CAA). Aos 38 anos passou apresentar sudorese excessiva com limite superior em T4, diária, com intensificação noturna. Um bloqueio simpático lombar foi efetuado corn $4 \mathrm{~mL}$ de bupivacaina $0.5 \%$. Quinze minutos depois a paciente apresentou monoparesia braquial direita e síndrome de Homer ipsolateral. Devido provavelmente a um espaço peridural estreito e errático, secundário à CAA, pode-se justificar o quadro clínico como secundário à ascenção cranial do anestésico, mesmo utilizado em reduzida quantidade $(4 \mathrm{~mL})$.

PALAVRAS CHAVE: bloqueio simpático lombar, aracnoidite crônica adesiva, síndrome de Horner.

Deficits of the cervical sympathetic chain causing Horner's syndrome following anesthetic blocks of the cervical or supraclavicular regions are well known but are rarely seen when this procedure is performed in other areas ${ }^{5,8}$. The lumbar sympathetic block induces a sympathetic deficiency restricted to the lower limbs.

The present patient is a woman with excessive and predominantly nocturnal sweating below the T4 level secondary to chronic adhesive arachnoiditis (CAA). Shortly after a $4 \mathrm{ml} 0.5 \%$ bupivacaine lumbar sympathetic block she presented a right brachial paresis and an ipsilateral Horner's syndrome. To the best of our knowledge, no similar case has been reported. The authors believe it is important for neurologists and anaesthesiologists to be aware of this possibility.

Department of Neurosurgery, National Cancer Iinstitute (INCa), Rio de Janeiro, Brazil: * Neurologist; ** Anaesthesiologist; *** Neurosurgeon. Aceite: 11-maio-1995.

Dr. Péricles A. Maranhão Filho, - Av. Canal de Marapendi 1680 apt 1802. - 22631-050 Rio de Janeiro RJ Brasil. Fax (+55.21) 4395594. 


\section{CASE REPORT}

MMXY, a 40 -year-old white woman, complained of fatigue, progressive weakness of the lower limbs and frequent falls from the age of 31 , three months after an intrathecal (spinal) anesthesia because of a caesarean delivery. This procedure had been performed before twice. One year later the symptoms worsened and she began complaining of numbness up to the thorax. A myelography showed a spinal subarachnoid block at T4T7. The diagnosis of CAA was considered based on the analysis of the meninges following a laminectomy at the appropriate level. Six years later she started having profuse sweating below the T4 level, more frequently at night. Although there was no pain, the intensity of the sweating did not allow her to sleep, as she had to change clothes and bed linen every so often. Two years later she was seen in our Department.

The patient was in a wheel-chair with a pyramidal-type paraplegia. There was a superficial and deep sensory deficit with an upper level at T4 together with bladder and rectal incontinence. The temperature in the lower limbs was felt as asymmetric, colder at the right side. The cranial nerves and the upper limbs were nomal.

A sympathetic block was thought to be the best treatment for her autonomic dysfunction. After the identification of the epidural space at the T12-L1 level according to the Dogliotti technique, a catheter $(5 \mathrm{~cm})$ was placed accordingly and $4 \mathrm{~mL} 0.5 \%$ bupivacaine without adrenaline was injected. The patient was lying at her left side. During the injection she complained of electricity-like shocks spreading down to the lower limbs and up to the right upper limb. Fifteen minutes later, a right brachial paresis and an ipsilateral Homer's syndrome (pseudoptosis, miosis, enophthalmus, dilatation of the conjunctival vessels) were noted. This lasted for four hours and then subsided partially. During the next following week the patient underwent the same procedure twice a day. There were no further electricity-like shocks but the motor and autonomic signs recurred constantly.

One week after the sympathetic block sessions the patient had a mild paresis of the right hand and an incomplete right Homer's syndrome (pseudoptosis and miosis). The sweating level changed from $\mathrm{T} 4$ to $\mathrm{T} 10$ but its intensity did not improve.

\section{COMMENTS}

The Claude Bernard-Homer's syndrome was described in humans by Johann Friedrich Horner, a Swiss ophthalmologist, in 1869; and in animals by many authors, among them Claude-Bernard ${ }^{7}$. This syndrome is characterized by pseudoptosis (paralysis of the upper lid plus elevation of the lower lid due to paralysis of the tarsal muscles), miosis, enophthalmus, and anhidrosis. In addition, there may be vasodilation in the face, neck and conjunctiva ipsilaterally, heterochromia of the irises and hemifacial atrophy when the deficiency is congenital or long-lasting. Pseudoptosis and miosis are the most common signs ${ }^{4}$.

The sympathetic innervation of the head involves preganglionic fibres arising from the spinal cord through C8-T1 (eventually T4) ventral roots. The fibres enter the superior, middle and inferior cervical ganglia where they synapse. Postganglionic fibers come along with the internal carotid artery through the cavernous sinus and reach the orbit following the ophthalmic branch of the trigeminal nerve. They supply the ciliary and tarsal muscles, and the orbital muscle of Müller.

Horner's syndrome due to lumbar epidural anesthesia has been described in pregnant women in connection to normal and caesarean delivery ${ }^{35,6}$. It seems likely that the epidural space of pregnant women is reduced in size as a result of dilation of the epidural veins ${ }^{6}$. According to Cleyton ${ }^{3}$, the incidence of Horner's syndrome in women given extradural analgesia during labor was $1.33 \%$; and $4 \%$ in those undergoing elective caesarean operation under extradural block.

Epidural space injection with the patient lying laterally was reported to produce analgesia of the side that is lowers.

Bum et al. ${ }^{2}$ used epidurograms to study the spread of solutions injected into the extradural space. They showed that $40 \mathrm{~mL}$ solutions injected caudally or at the lumbar region reach the upper thoracic and lower cervical segments, but not $20 \mathrm{~mL}$ or less. They also postulated that the rate of injection, the posture, height and age of the patient were all insignificant for determining the extent of the spread. 
Blomberg ${ }^{1}$ performed epiduroscopy in 48 autopsy subjects and described a dorsal connective tissue band in the midline of the epidural space between the dura mater and the flaval ligaments in all cases. He claims that this connection fixes the dura mater to the flaval ligaments and narrows the epidural space in the midline.

The existence of the dorsomedian connection might help to explain some of the unexpected events that may occur during clinical epidural anaesthesia. Variations in the paravertebral space could interfere with the amount of cranial spread".

In conclusion, it is suggested that this patient may have a restricted and erratic epidural space due to CAA. This could provoke an increased cephalic spread of the injected solution with a subsequent higher unilateral sympathetic and motor effects, as the upper side was affected with only $4 \mathrm{~mL}$ of the anaesthesic.

Aknowledgement - We are indebted to Dr. Maurice Vincent for assistance.in preparing this manuscript.

\section{REFERENCES}

1. Blomberg $\mathbf{R}$. The dorsomedian connective tissue band in lumbar epidural space of humans: an anatomical study using epiduroscopy in autopsy cases. Anesth Analg. 1986, 65:747-752.

2. Burn JM, Guyer PB, Langdon L. The spread of solutions injected into the epidural space. Br. J Anaesth 1973, 45:338-345.

3. Clayton KC. The incidence of Horner's syndrome during lumbar extradural for eletive caesarean section and provision of analgesia during labor. Anaesthesia 1983, 38:583-585.

4. DeJong RN. The neurologic examination. Ed 4. New York: Harper \& Row, 1979, p 127.

5. Evans JM, Gauci CA, Watkins G. Horner's syndrome as a complication of lumbar epidural block. Anesthesia 1975, 30:774-777.

6. Mohan J, Potter JM. Pupillary constriction and ptosis following caudal epidural analgesia. Anaesthesia 1975, 30:769-773.

7. Wilkins RH, Brody IA, Durham NC. Horner's Syndrome. Arch Neurol 1968, 19:540-542.

8. Wills MH, Korbon GA, Arasi R. Horner's syndrome resulting from a lumbar sympathetic block. Anesthesiology 1988, 68:613-614. 